\title{
GAS EXCHANGE, PHISIOLOGICAL INDEXES AND IONIC ACCUMULATION IN Annona emarginata (Schltdl.) H. Rainer SEEDLINGS IN NUTRIENTS SOLUTION ${ }^{1}$
}

\author{
DANIEL BARON ${ }^{2}$, GISELA FERREIRA ${ }^{3}$, JOÃO DOMINGOS RODRIGUES ${ }^{3}$, \\ CARMEN SÍLVIA FERNANDES BOARO ${ }^{4}$, ANA CLÁUDIA MACEDO
}

\begin{abstract}
Araticum-de-terra-fria" (Annona emarginata (Schltdl.) H. Rainer) has been consider a good alternative in rootstock production for the main commercial Annonaceae species. Although this species develops in different soil and climate conditions, there is no understanding by the physiological responses of this species at different nutritional levels. Thus, the objective of this study was to evaluate the influence of different ionic strengths on development of vegetative species known as "Araticum-de-terra-fria". It was evaluated in seedlings grown in different ionic strengths $(25 \% I, 50 \% I, 75 \% I$ and $100 \% I)$ of the complete nutrient solution Hoagland and Arnon (1950) $\mathrm{n}^{\circ}$ 2, for 140 days, the following characteristics: Gas Exchange $\left(\mathrm{CO}_{2}\right.$ assimilation rate, stomatal conductance, internal $\mathrm{CO}_{2}$ concentration, transpiration rate, water use efficiency, Rubisco carboxylation efficiency); Vegetative growth characteristics (diameter, leaf number, dry matter); Physiological Indexes (leaf area ratio, specific leaf area, relative growth rate, net assimilation rate, leaf weight ratio) and Ionic Accumulation (nutrients leaf analysis). Seedlings grown under $50 \% I$ showed the highest values of Leaf $\mathrm{CO}_{2}$ assimilation rate, water use efficiency, carboxylation efficiency, growth, relative growth rate, net assimilation rate and ionic accumulation in the total dry matter. So it is concluded that "Araticum-de-terra-fria" seedlings grown under intermediate nutrient concentrations of complete nutrient solution Hoagland and Arnon (1950) $n^{\circ}$ 2, explored more adequately their physiological potential that justify their adaptation in different nutritional conditions and allow reducing the amount of mineral nutrition of seedlings production.
\end{abstract}

Index terms: Annonaceae, Araticum-de-terra-fria, seedlings, rootstock, macronutrients.

\section{TROCAS GASOSAS, ÍNDICES FISIOLÓGICOS E ACÚMULO IÔNICO EM PLANTAS JOVENS DE Annona emarginata (Schltdl.) H. Rainer EM SOLUÇÃO NUTRITIVA}

\begin{abstract}
RESUMO - "Araticum-de-terra-fria" (Annona emarginata (Schltdl.) H. Rainer) tem sido considerada uma boa alternativa na produção de porta-enxertos para as principais espécies comerciais da família botânica Annonaceae, tais como atemoia, fruta-do-conde (ou pinha) e cherimólia. Embora esta espécie se desenvolva em diferentes tipos de solos e condições climáticas, não está elucidado como ela responde fisiologicamente sob diferentes disponibilidades nutricionais. Desta maneira, o objetivo deste estudo foi avaliar como diferentes forças iônicas interferem no desenvolvimento de plantas jovens desta espécie, também conhecida como "Araticum-de-terra-fria". Avaliaram-se, em plantas jovens de "araticum-de-terra-fria", cultivadas em diferentes forças iônicas ( $25 \%$ FI, $50 \%$ FI, $75 \%$ FI e 100\% FI) da solução nutritiva completa n $^{\circ} 2$ de Hoagland e Arnon (1950), por 140 dias, as seguintes características: Trocas Gasosas (assimilação de carbono, condutância estomática, concentração de carbono interno, transpiração, eficiência do uso da água e eficiência de carboxilação da enzima Rubisco); Crescimento Vegetativo (diâmetro de caule, número de folhas, altura e massa de matéria seca); Índices Fisiológicos (razão de área foliar, área foliar específica, taxa de crescimento relativo, taxa de assimilação líquida de carbono, razão de massa foliar e Acúmulo Iônico (análise foliar). As plantas cultivadas em $50 \%$ de força iônica foram aquelas com os maiores valores de assimilação de carbono, eficiência do uso da água, eficiência da enzima Rubisco, taxa de crescimento relativo, taxa de assimilação líquida de carbono e acúmulo iônico das folhas. Conclui-se que plantas jovens de "araticum-de-terra-fria", mantidas em concentrações intermediárias de nutrientes da solução nutritiva completa $\mathrm{n}^{\circ} 2$ Hoagland and Arnon (1950), exploraram seu potencial fisiológico, o que justifica sua adaptação em diferentes condições nutricionais e permite reduzir a quantidade de elementos minerais na produção de mudas.
\end{abstract}

Termos para indexação: Annonaceae, Araticum-de-terra-fria, produção de mudas, porta-enxerto.

\footnotetext{
'(Trabalho 229-12). Recebido em: 27-08-2012. Aceito para publicação em: 10-05-2013.

${ }^{2} \mathrm{MSc}$ in Biological Sciences (Botany), São Paulo State University (UNESP), Botucatu, SP, E-mail: danielbaron.agro@gmail.com.br ${ }^{3}$ Doctor in Agronomy, São Paulo State University (UNESP), Botucatu, SP. E-mail: gisela.unesp@yahoo.com.br; mingo@ibb.unesp.br; ${ }^{4}$ Doctor in Biological Sciences (Botany), São Paulo State University (UNESP), Botucatu, SP. E-mail: csfboaro@ibb.unesp.br ${ }^{5} \mathrm{MSc}$ in Agronomy (Horticulture), São Paulo State University (UNESP), Botucatu, SP, E mail:anamacedo85@gmail.com
} 


\section{INTRODUCTION}

The genus Annona includes several economically important subtropical and tropical fruit tree species including cherimoya ( $A$. cherimola Mill.), soursop (A. muricata L.), sugar apple ( $A$. squamosa L.), and atemoya (A. squamosa L. $\times$ A. cherimola Mill). The species of the genus Annona can present importance in folk medicine as Anticarcinogenic treatment, antipyretic effects, cramps, diarrhea and digestive problems; action in agriculture as a natural insecticide; ecological and ornamental, ecological recovery of degraded areas (Annona rugulosa Schltdl.) and power base of animals belonging to local wildlife (MITTAL et al., 2010; OKOYE et al., 2012).

The production of high-quality seedlings requires a rootstock compatible with the canopy and resistant or tolerant to pathogens (PADILLA and ENCINA, 2011). Thus, the species Annona emarginata (Schltdl.) H. Rainer variety "terrafria" has been successfully evaluated, although empirically, as an alternative for the production of atemoya, soursop and cherimoya seedlings (BETTIOL NETO et al.,2006). In addition, the normal nutrient patterns in leaf dry matter over the cultivation time must be known since they provide highly important information for a nutritional management plan aimed at meeting the demand for nutrients (FRANCO and PRADO, 2008) and assuring the advantages of clonal propagation and consequently productivity.

However, since $A$. emarginata species is native from the South American continent and present natural occurrence in nutritionally poor soil regions, this species still little studied, its physiological behavior must be assessed, especially at the initial development stage, in order to provide information to safely enhance the production of highquality seedlings, assuring the increasing demand of the international market for Annonaceae fruits (BETTIOL NETO et al., 2006).

Besides, several nutrient solutions have already been proposed to fruits (Fig plants), vegetable crops (lettuce plants) and, in some cases, there are remarkable and excessive differences in the employed macro and micronutrient concentrations (SEVIL KILINC et al., 2007; HELBEL JUNIOR et al., 2008). Although the nutritional solutions super estimate the quantities of nutrients offered the plants these are important for the study of the nutritional needs of plant species, in which the variation of the concentrations of nutrients in these solutions may reflect the real needs of the vegetal (RESH, 2001).
As, however, there are no studies that evaluate the needs of the species Araticum-de-terra-fria, a possible starting point is the variation of nutrient concentration in nutrient solution no. 2 of Hoagland and Arnon (1950).

Photosynthetic and developmental patterns are affected by variations in the availability of mineral elements due to the direct effect of the last on several metabolic steps; however, in our literature review, descriptions of how these mechanisms are set for Araticum-de-terra-fria were not found. In addition, nutrient solutions have been widely used in studies on plant physiology, especially those related to mechanisms coordinating the plant growth (LARCHER, 2006; MARSCHNER, 2012).

In this context, different ionic strengths of nutrient solution do not affect the development of Araticum-de-terra-fria plantlets. So, the objective of this study was to evaluate the influence of different ionic strengths of Hoagland and Arnon (1950) solution on some physiological and developmental of Annona emarginata (Schltdl.) H. Rainer variety "terra-fria".

\section{MATERIAL AND METHODS}

Experimental local and plant material. The experiment was carried out in a greenhouse in Botucatu Municipality, State of São Paulo, Brazil, between July 2008 and February 2009. This locality presents the following geographic coordinates: $48^{\circ}$ $24^{\prime} 35^{\prime \prime} \mathrm{W}, 22^{\circ} 49^{\prime} 10^{\prime \prime} \mathrm{S}$ and $850 \mathrm{~m}$ mean altitude above the sea level. Annona emarginata (Schltdl.) H. Rainer variety "terra-fria" seeds were subjected to phytosanitary treatment with sodium hypochlorite $(1 \%)$ and fungicide CAPTAN $^{\circledR}$ at $0.2 \%$ active ingredient. After this treatment, sowing was done on polystyrene trays filled with expanded vermiculite. When seedlings presented $7-10 \mathrm{~cm}$ (height) mean size, they were transplanted to pots of around $1.5 \mathrm{~L}$ volume filled with continuously aerated nutrient solution.

Treatments. Treatments consisted of varying ionic concentrations (ionic strength, $I$ ) of complete nutrient solution Hoagland and Arnon (1950) $\mathrm{n}^{\circ} 2$ which had a concentration of $100 \%$ and was thus considered $100 \%$ I, electrical conductivity $(2.0 \pm$ $\left.0.02 \mathrm{mS} \mathrm{cm} \mathrm{cm}^{-1} \mathrm{EC}\right)$. From the initial concentration, subsequent dilutions were done in demineralized water up to a concentration of $75 \%$, i.e. $75 \% I(1.50$ $\left.\pm 0.2 \mathrm{mS} \mathrm{cm}^{-1} \mathrm{EC}\right)$, and successively to $50 \% I(1.00$ $\left.\pm 0.2 \mathrm{mS} \mathrm{cm}^{-1} \mathrm{EC}\right)$ and $25 \% \mathrm{I}\left(0.5 \pm 0.02 \mathrm{mS} \mathrm{cm}^{-1}\right.$ EC). The volume of PA salts (pure for analysis) used as macronutrient sources $\left[\mathrm{NH}_{4} \mathrm{H}_{2} \mathrm{PO}_{4}, \mathrm{KNO}_{3}\right.$, 
$\mathrm{Ca}\left(\mathrm{NO}_{3}\right)_{2} \cdot 4 \mathrm{H}_{2} \mathrm{O}$ and $\left.\mathrm{MgSO}_{4} \cdot 7 \mathrm{H}_{2} \mathrm{O}\right]$ were $0.50,1.50$, 1.0 and $0.5 \mathrm{~mL} \mathrm{~L}^{-1}$, respectively, in the Treatment $25 \%$ I; 1.0, 3.0, 2.0 and $1.0 \mathrm{~mL} \mathrm{~L}^{-1}$ in the Treatment $50 \% \mathrm{I}$; $1.5,4.50,3.0$ and $1.50 \mathrm{~mL} \mathrm{~L}^{-1}$ in the Treatment $75 \%$ I; and 2.0, 6.0, 4.0 and $2.0 \mathrm{~mL} \mathrm{~L}^{-1}$ in the Treatment $100 \% \mathrm{I}$ (control). For micronutrient sources $\left(\mathrm{H}_{3} \mathrm{BO}_{3}\right.$; $\mathrm{MnCl}_{2} \cdot 4 \mathrm{H}_{2} \mathrm{O} ; \mathrm{ZnSO}_{4} \cdot 7 \mathrm{H}_{2} \mathrm{O} ; \mathrm{CuSO}_{4} .5 \mathrm{H}_{2} \mathrm{O} ; \mathrm{H}_{2} \mathrm{MoO}_{4}$. $\mathrm{H}_{2} \mathrm{O}$; Fe-EDTA and $\left.\mathrm{FeSO}_{4} .7 \mathrm{H}_{2} \mathrm{O}\right), 0.25 \mathrm{~mL} \mathrm{~L}^{-1}$ of each salt was used in the Treatment $25 \% I ; 0.50$ $\mathrm{mL} \mathrm{L}^{-1}$ in the Treatment $50 \% \mathrm{I} ; 0.75 \mathrm{~mL} \mathrm{~L}^{-1}$ in the Treatment $75 \% \mathrm{I}$; and $1.0 \mathrm{~mL} \mathrm{~L}^{-1}$ in the Treatment $100 \%$ I (Table 1). The electrical conductivity (EC) of the nutrient solution was daily monitored by using a laboratory bench EC meter (DIGIMED ${ }^{\circledR}, \mathrm{CD}-21$ model), and $\mathrm{pH}$ was daily adjusted to $6.0 \pm 0.5$ by using a laboratory bench $\mathrm{pH}$ meter (DIGIMED ${ }^{\circledR}$, DMPH-3 model). The nutrient solution was renewed weekly or whenever safety intervals changed for each Treatment $\left( \pm 0.2 \mathrm{mS} \mathrm{cm}^{-1}\right.$ relative to the original value used in each Treatment), and demineralized water was employed to replace the evapotranspirated water. The control of pests in "Araticum-de-terrafria" seedlings was done through manual cleaning (cochineals) and by using tobacco syrup, known as natural insecticides which represent low risk to the environment.

Gas exchange. It was used the open system Infra-Red Gas Analyzer (IRGA, LI-6400 model, LI-COR) with $\mathrm{CO}_{2}$ and water vapor measured through infrared radiation. These measurements were performed at 63, 98 and 126 DAT (Days After Transplant) from 9 to 11 a.m., on a sunny day, by selecting 5 plants (replicates) per Treatment, choosing and standardizing their second or third fully expanded leaf. The evaluated Gas Exchange features were: net $\mathrm{CO}_{2}$ assimilation rate $\left(A_{\text {net }}, \mu \mathrm{mol}\right.$ $\left.\mathrm{CO}_{2} \mathrm{~m}^{-2} \mathrm{~s}^{-1}\right)$, stomatal conductance $\left(g_{s}, \mathrm{~mol} \mathrm{~m}^{-2} \mathrm{~s}^{-1}\right)$, internal $\mathrm{CO}_{2}$ concentration $\left(C_{\mathrm{i}}, \mu \mathrm{mol} \mathrm{CO} \mathrm{Col}^{-}\right.$ ${ }^{1}$ air) and transpiration rate $(E, \mathrm{mmol}$ water vapor $\left.\mathrm{m}^{-2} \mathrm{~s}^{-1}\right)$. Water use efficiency (WUE, $\mu \mathrm{mol} \mathrm{CO}_{2}$ $\left.\left(\mathrm{mmol} \mathrm{H}_{2} \mathrm{O}\right)^{-1}\right)$ was determined through the ratio between $\mathrm{CO}_{2}$ assimilation and transpiration rate $\left(A_{\text {net }} / E\right)$ and the Rubisco (Ribulose 1,5-Bisphosphate Carboxylase/Oxygenase, EC 4.1.1.39) instantaneous carboxylation efficiency $\left(A_{\text {net }} / C_{\mathrm{i}}\right)$.

Ionic accumulation. The levels of nitrogen $(\mathrm{N})$, phosphorus $(\mathrm{P})$, potassium $(\mathrm{K})$, calcium $(\mathrm{Ca})$, magnesium $(\mathrm{Mg})$ and sulfur $(\mathrm{S})$ in the leaves were quantified at 28, 56, 112 and 140 DAT in the Laboratory of Plant Mineral Nutrition, Department of Natural Resources/Soil Sciences, School of Agronomical Sciences (FCA), São Paulo State University "Júlio de Mesquita Filho" (UNESP), Botucatu campus, State of São Paulo, Brazil. Based on these results, calculations for unit adequacy were done, i.e. conversion of $\mathrm{g} \mathrm{kg}^{-1}$ into $\mathrm{g}$ plant $\mathrm{t}^{-1}$, for each mineral element accumulated in the plant.

Vegetative Growth. At 28, 56, 84, 112 and 140 DAT, the following characteristics were measured: stem diameter $(\mathrm{mm})$; height $(\mathrm{cm})$; leaf number (units); and leaf area $\left(\mathrm{cm}^{2}\right)$ with an area meter (LI$\mathrm{COR}^{\circledR}$, LI-3100 model). The plant material was washed in demineralized water and dried in a forced aeration oven at $65^{\circ} \mathrm{C}$ until constant weight in order to obtain leaf, stem, root and total dry matter $(\mathrm{g})$, measured with an analytical balance of up to $0.001 \mathrm{~g}$ sensitivity.

Physiological Indexes. Harvests were performed at 28, 56, 84, 112 and 140 DAT, using 5 plants (replicates) per Treatment in each evaluation period. The seedlings were separated into leaf, stem and root and leaf with results expressed as square decimeters $\left(\mathrm{dm}^{2}\right)$. After quantification of leaf area and total and leaf dry matter at every 28 days until the final experimental period (140 DAT), the physiological indexes RGR (Relative Growth Rate), NAR (Net Assimilation Rate), LAR (Leaf Area Rate), SLA (Specific Leaf Area) and LWR (Leaf Weight Rate) were obtained through their respective mathematical formulas, according to the recommendation in several papers directed to quantitative growth analysis. Thus, the total dry matter, leaf blade and leaf area plants, submitted to the different Treatments, were adjusted as a function in the time, considering the version $\ln$ $y=a+b t+c t^{2}$ to dry matter $>0$, according to the equations: $\operatorname{DM}(y)=a . e\left(b t+c^{2}\right)$ and $L A(y 1)=a_{1}$.e $\left(b_{1} t+c_{1} t^{2}\right)$, where DM, dry matter and LA, leaf area (RADFORD, 1967). The physiological indexes RGR and NAR were calculated by solving the integrals through numerical methods for each replicate of all Treatments by using the software SAS. To calculate $\mathrm{RGR}$, in $\mathrm{g} \mathrm{g}^{-1} \mathrm{day}^{-1}$, it is assumed that new growth is simply a function of the existent dry matter and this index is a function of the initial size, i.e. the increase in grams. It was calculated by the equation: RGR $=\mathbf{1} / \mathbf{( T D M}) . \mathbf{d T D M} / \mathbf{d t}$, where $\mathrm{d} / \mathrm{dt}=(\log \mathrm{TDM})$; TDM represents the total dry matter. NAR, in $g$ $\mathrm{dm}^{-2}$ day $^{-1}$, expresses the net photosynthesis rate, in terms of produced dry matter, in grams, per square decimeter of leaf area, per time unit: NAR $=\mathbf{1}$ / (LA) $\mathbf{d T D M} / \mathbf{d t}$, where: $\mathrm{d} / \mathrm{dt}=(\log \mathrm{TDM})$; TDM represents the total dry matter. LAR, in $\mathrm{dm}^{2} \mathrm{~g}^{-1}$, expresses the useful leaf area for photosynthesis and was obtained from the instantaneous values of leaf area (LA), responsible for the interception of light energy and $\mathrm{CO}_{2}$, and total dry matter (TDM), resultant from photosynthesis. LAR is considered a measurement of the photosynthetic capacity of a plant according 
to the equation: $\mathbf{L A R}=\mathbf{L A} / \mathbf{T D M}$. SLA, in $\mathrm{dm}^{2}$ $\mathrm{g}^{-1}$, indicates the inverse of leaf thickness and was obtained through the ratio between leaf area (LA) and leaf dry matter (LDM): SLA = LA/LDM. LWR is expressed as $\mathrm{g} / \mathrm{g}$ and defined as the ratio between leaf dry matter (LDM) and total dry matter (TDM): $\mathbf{L W R}=\mathbf{L D M} / \mathbf{T D M}$.

Experimental Delineament and Statistical Analysis. The plants were conducted and distributed into randomized blocks with four Treatments and five replicates, each one composed of one plant. Five data collections were done to measure plant growth and calculate the physiological indexes, in addition to three collections to evaluate leaf gas exchange, and four collections to analyze leaf nutrients. Data on plant growth variables were subjected to analysis of variance (ANOVA), and means compared by Tukey's Test at $5 \%$ significance $(P \leq 0.05)$. Statistical analyses were done by using the software SAS, version 9.0 (LITTELL et al., 2002).

\section{RESULTS AND DISCUSSION}

The humidity and temperature data recorded over the cultivation period for "Araticum-de-terrafria" seedlings in greenhouse are described in Figure 1. The Treatments resulted in changes in both variables of gas exchange and ionic accumulation which also resulted in changes in the patterns of development.

Gas Exchange. As regards photosynthetic responses, it must be emphasized that the access of the atmospheric $\mathrm{CO}_{2}$ to the photosynthetic cells from the mesophyll occurs through stomatal opening and, therefore, variations in the stomatal conductance $\left(g_{\mathrm{s}}\right)$ directly affect $A$ and $E$ (ÁLVAREZ et al., 2011). In addition, $g_{\mathrm{s}}$ is influenced by the environment (CAMPOSTRINI et al., 2010), abscisic acid (MAHOUACHI et al., 2006) and mineral nutrition (MARSCHNER, 2012). In plants grown under $100 \% I$, transpiration rate $(E)$ decreased (Figure 3C), whereas $A$ values were stable up to 98 DAT and decreased up to $126 \mathrm{DAT}$, similarly to $A_{\text {net }} / C_{\mathrm{i}}$ (Figure 3B), which resulted in $\mathrm{CO}_{2}$ accumulation in the leaves (Figure 3F). Thus, there was higher $W U E$ (Figure 4E) even with lower Rubisco activity since $E$ values decreased over time. The reduction in $A$ and $E$ values observed for plants kept under $100 \% I$, reaching the lowest values at 126 DAT (Figure 3A and $3 \mathrm{~B})$, can be explain by increased EC in the nutrient solution may lead to reduced vegetative development for either the whole plant or individual parts due to ion accumulation (EVETT et al., 2012), directly affecting photosynthesis (CHATZISSAVVIDIS and

\section{THERIOS, 2010).}

Araticum-de-terra-fria seedlings kept in nutrient solution of $25 \% \mathrm{I}$ had low net $\mathrm{CO}_{2}$ assimilation rate $\left(A_{\text {net }}\right)$ (Figure $\left.3 \mathrm{~A}\right)$, lower instantaneous carboxylation efficiency $\left(A_{\text {net }} / C_{\mathrm{i}}\right)$ (Figure 3B), and increased transpiration $(E)$ (Figure $3 C)$, which resulted in lower water use efficiency (WUE) (Figure 3D). It must be emphasized that the increased conductance $\left(g_{\mathrm{s}}\right)$ (Figure 3E) from 98 DAT did not lead to a higher net $\mathrm{CO}_{2}$ assimilation rate; there was also higher internal $\mathrm{CO}_{2}$ concentration $\left(C_{\mathrm{i}}\right)$ (Figure 3F). Furthermore, the highest $C_{\mathrm{i}}$ values were detected under $25 \% \mathrm{I}$, especially up to $98 \mathrm{DAT}$ (Figure 3C), which is a result of the low efficiency of Rubisco in the carboxylation (Figure 3F). Thus, even with an increasing $E$ in this period (Figure 3D) and a tendency toward increased stomatal conductance (Figure 3B), there was not $\mathrm{CO}_{2}$ influx into the leaf due to the failure caused in the photosynthetic apparatus by the low ion availability in the nutrient solution, preventing the chemical potential reduction of the internal $\mathrm{CO}_{2}$ and consequently a higher $\mathrm{CO}_{2}$ influx into the leaf. A lower Rubisco activity leads to a lower organic synthesis, and since $E$ is high, there is a decrease in $W U E$. Plants kept under $25 \% I$ had the lowest $W U E$ values (Figure 3D), which may have directly influenced the stomatal conductance of seedlings and subsequently the enzymatic activities (BENLLOCH-GONZÁLEZ et al., 2010), affecting the use of mineral nutrients (WANG et al., 2010). The dependence of $W U E$ on water and nutrient supply for $\mathrm{C}_{3}$ plants was demonstrated in several studies, including that of Kumar and Dey (2011) with strawberry, De Barros et al. (2007) with corn, peanut and Sun et al. (2006) with wheat plants.

Plants kept under 50\% I presented higher $A_{\text {net }}$ values, relative to those under the remaining ionic strengths, from the first evaluation, even with patterns of $g_{\mathrm{s}}$ close to those under more elevated ionic strengths up to 98 DAT. On the other hand, $A_{\text {net }}$ and $A_{\text {net }} / C_{\mathrm{i}}$ values decreased up to $98 \mathrm{DAT}$, which resulted in $\mathrm{CO}_{2}$ accumulation. The lower $A_{\text {net }} / \mathrm{C}_{\mathrm{i}}$ values may be due to the increased mean air temperature (Figure 1), since this species presents $\mathrm{C}_{3}$ metabolism, the ideal temperature of which ranges from 25 to $30^{\circ} \mathrm{C}$. However, the plants rapidly adapted, increasing $A_{\text {net }}$ values. The higher $A_{\text {net }}$ values for plants kept under $50 \% I$, relative to the remaining Treatments (Figure 3A), may be due to the better utilization of the provided mineral elements, which resulted in increased photosynthetic rates for mature leaves or even higher photosynthetic capacity of the leaves (TUCCI et al., 2011).Thus, $A_{\text {net }}$ and $A_{\text {net }} / C_{\mathrm{i}}$ values detected for plants grown under $50 \% I$ were higher 
in general (Figure $3 \mathrm{~A}$ and $3 \mathrm{~F}$ ), relative to those observed for the remaining Treatments. Besides, those plants had high $E$ values are related to the high rates of $\mathrm{CO}_{2}$ assimilation and probably high water consumption, implying an enhanced development of the species (THONGBAI et al., 2010). The decreased $E$ and increased $A_{\text {net }}$ values, mediated by Rubisco activity, resulted in higher WUE for such plants (Figure 3F). It should be highlighted, therefore, that $\mathrm{CO}_{2}$ diffusion and water loss through transpiration are independent processes (LARCHER, 2006). In addition, transpiration can be considered a "necessary cost" associated with stomatal opening to allow $\mathrm{CO}_{2}$ diffusion from the air to photosynthesis (AFROUSHEH et al., 2010), besides allowing the mass flow of the mineral nutrients absorbed in the roots to the shoot (MARSCHNER, 2012); however, $A_{\text {net }}$ and $E$ are not always dependent variables, as observed in the present study. Among the factors that affect photosynthesis are the mineral elements (TAIZ and ZEIGER, 2010) the different ionic strength affect photosynthesis differently, as can be seen by the results. Considering therefore that ionic strength altering gas exchange, it must be determined how this 'pool' of elements were accumulated causing such changes.

Ionic Accumulation. The analysis of significant interactions between the evaluation periods and the different ionic strengths indicated that $25 \% I$ led to the lowest accumulation of all elements, which had significantly lower levels over time, differing from the results for $50 \% \mathrm{I}$, which led to the highest accumulation, especially at 112 and 140 DAT (Figure 4), and did not differ from 75 and $100 \% I$ in some evaluations. Thus, significant accumulations of $\mathrm{N}, \mathrm{P}, \mathrm{Ca}, \mathrm{Mg}$ and $\mathrm{S}$ in the total dry matter were detected from $112 \mathrm{DAT}$, whereas $\mathrm{K}$ had a singular behavior, with accumulations from 56 DAT and no difference from 140 DAT. The specific observation of each element showed that $\mathrm{N}$ had higher accumulation in the plants kept under 50 and $75 \% I$ at 112 DAT $\left(0.12 \mathrm{~g} \mathrm{plant}^{-1}\right)$ and under $50 \% I$ at 140 DAT $\left(0.13\right.$ g plant $\left.^{-1}\right)$ (Figure 4A). Phosphorus and potassium presented significant accumulation at 112 and 140 DAT in the plants grown under $50 \% I$ [Figure 4B $\left(0.01 \mathrm{~g} \mathrm{plant}^{-1}\right)$ and $4 \mathrm{C}\left(0.06 \mathrm{~g} \mathrm{plant}^{-1}\right)$, respectively]. Calcium (Figure 4D) and sulfur (Figure 4E) had a similar behavior, with higher values under $50 \% I$ at 112 DAT and no difference from 75 and $100 \%$ I at 140 DAT; however, $\mathrm{Mg}$ was significantly lower for plants kept under $100 \% I$ (Figure $4 \mathrm{~F}$ ) in the last evaluation.

Thus, the ionic strength of $50 \% I$ was observed efficiency maximum of mineral elements with operations in photosynthesis, since the nitrogen, which is essential for the biochemical composition of several non-protein compounds such as coenzymes, secondary metabolites, polyamines, photosynthetic pigments (BENLLOCH-GONZÁLEZ et al., 2010) and fundamental role in the activity or quantity of Rubisco (URBAN, 2012). Thus, $A_{\text {net }}$ is closely related to the leaf $\mathrm{N}$ level (BAR-YOSEF, 2008; BAR-YOSEF et al., 2009), corroborating the present results, since the highest accumulation of this element was observed at the end of the experiment (Figure 4A), and the highest $A_{\text {net }}$ values were detected for plants kept under $50 \% I$ (Figure $3 \mathrm{~A}$ ). Phosphorus is another element of great importance; it is considered crucial to keep phosphorylation reactions during $\mathrm{CO}_{2}$ assimilation (WARD et al., 2011) besides positively helping other photosynthetic parameters such as $g_{\mathrm{s}}$ and $W U E$ (NAEEM et al., 2010), which were observed in the present study when plants were grown under 50\% I. Phosphorus levels below those ideal for plants result in decreased $A_{\text {net }}$ values since many intermediate steps of $\mathrm{CO}_{2}$ fixation involve phosphate sugars (MAATHUIS, 2009). Potassium is closely related to stomatal regulation, transpiration and osmoregulation (MARSCHNER, 2012). The present results showed that $A_{\text {net }}$ values decreased as potassium availability was lower (FAN et al., 2011). Calcium plays a structural role in the cells and signalizes some plant responses to the environment, e.g. stomatal regulation (MCAINSH and PITTMAN, 2009). The apparent absence of effect on photosynthesis is due to the small quantities of this element needed for this metabolic activity (TAN et al., 2011). Magnesium, accumulated in plants kept under $50 \%$ I from 112 DAT, plays a fundamental role in photosynthesis, specially inducing light reactions in the stroma (DINAKAR et al., 2012), and is required for thylakoid stacking, enzymes involved in $\mathrm{CO}_{2}$ assimilation and partition of assimilates between starch and sugars (DING et al., 2008). Sulfur, also first accumulated in plants kept under 50\% $I$ at 112 DAT, is responsible for the formation of sulfolipids, which are normally found at small proportions in the thylakoids (EPSTEIN and BLOOM 2006; IQBAL et al., 2012). Some plant proteins contain sulfur, such as ferredoxins, which participates in the photosynthetic process such as chlorophyll formation and electron transfer reactions (GILL et al., 2012). Thus, the suitable supply of mineral elements group led to a successful photosynthetic process, which resulted in higher plant development according to vegetative growth variables and physiological indexes (Table and Figure 2).

Vegetative Growth and Physiological Indexes. 
"Araticum-de-terra-fria" seedlings had significant differences in growth among Treatments over time, especially from 112 DAT, always with lower values for the plants grown under 25\% I (Table 2). Significant differences were observed for diameter, height, leaf area, and leaf, stem and total dry matter from 112 DAT, and the plants grown under 50\% presented the highest values relative to plants kept under $25 \%$, although $50 \%$ did not differ from plants kept under 75 and $100 \%$ at 112 and 140 DAT. The exception includes plants grown under $100 \% I$, the total dry matter of which decreased at 112 DAT (Table 2). As regards leaf number, the lowest values were obtained for plants kept under $25 \% \mathrm{I}$, also from 112 DAT, relative to the remaining Treatments, which were not significantly different (Table 2 ). However, significant differences in root dry matter were only observed at $140 \mathrm{DAT}$, with the highest values detected for plants kept under $50 \% \mathrm{I}$, significantly different from those kept under $25 \% I$.

Leaf area ratio (LAR) of plants grown under different ionic strengths decreased over the cultivation period (Figure 2A) and was not significantly different among Treatments (Table 3). Conversely, specific leaf area (SLA) values increased over time (Figure 2B), but without significant differences, similarly to LAR (Table 3). Specific leaf area (SLA) did not present a constant behavior over the studied period, independently of the evaluated Treatment. The adopted Treatments led to lower RGR for plants kept under 50, 75 and 100\% I over time, unlike those kept under 25\% I (Figure 2C). However, plants grown under $50 \%$ I had the highest mean RGR values, differing from those grown under $25 \%$ but not from those kept under 75 and 100\% I (Table 3). There was higher dry matter accumulation relative to the pre-existing material (RGR) for plants kept under 50, 75 and $100 \% \mathrm{I}$, with significant differences between mean values obtained under 50 and $25 \% I$ (Table 3). Thus, RGR showed a similar behavior to that described in the literature, with high values at the first intervals and subsequent decreases at the final intervals (DAVID et al., 2007). As regards net assimilation rate (NAR), there was a decrease over time for all Treatments, with the lowest values observed for plants under 25\% I (Figure 2D), which differed from those under $50 \%$, but both Treatments were not different from 75 and $100 \%$. Leaf weight ratio (LWR) had the highest values over time under $100 \% I$ and the lowest values under 25\% I (Figure $2 \mathrm{E})$; however, there were not significant differences in the mean total values among the different ionic strengths (Table 3). Net assimilation rate (NAR) is resultant of the interaction between variations in environmental factors (light, $\mathrm{CO}_{2}$, temperature, water and nutrient availability, leaf age etc.) and specific differences of each species, according to their genotype (LAMBERS et al., 2008). NAR indicates the efficiency of the assimilatory system involved in dry matter production, estimating thus the net photosynthesis in this case, the highest NAR value was detected in plants kept under 50\% I (Table 3), due to the better use of the supplied mineral elements. This results agree with those in studies developed in hydroponic systems with varying elements in the nutrient solution, including the studies of David et al. (2007), Alves (2008) and David and Boaro (2009), emphasizing that this comparison was done among plants of different species.

The Araticum-de-terra-fria seedlings responded to the different ionic strengths, with higher growth values (RGR and NAR) for plants kept under 50 and $75 \% I$, lower values for those kept under $25 \%$ $I$, and intermediate values for those under $100 \% I$. We can observed that drastic reductions in the supply of mineral elements $(25 \% I)$, significantly decrease the plant development, similarly to the results obtained by Batista et al. (2003) to soursop seedlings in different fertilizations levels. However, under 100\% $I$, which represents a "standard" solution for plants, photosynthesis and accumulation of mineral elements were lower, which shows that this species does not require large quantities of mineral elements to express its development potential. This plants seems to be similar a others wild plants adapted to nutrientpoor soils, that present a growth strategy named type I (slow growth), that are not more efficient in nutrient acquisition than cultivated or invasive species (type II, fast growth) (CHAPIN, 1980), besides low rate of maximum potential growth and low efficient use of nutrients when high strength ionic availability.

In this context, it can be concluded that, the use of $50 \% I$ was sufficient for an effective action of mineral elements on the different physiological processes, resulting in higher photosynthetic efficiency and consequently higher plant development that explain their rusticity and adaptation in different nutritional conditions. 
TABLE 1- Nutrient composition of different ionic strengths $(I)$ of complete nutrient solution $\mathrm{n}^{\circ} 2$ of Hoagland and Arnon (1950) used for the cultivation of "Araticum-de-terra-fria" seedlings.

\begin{tabular}{|c|c|c|c|c|c|}
\hline \multirow{2}{*}{$\frac{\text { Used compounds }^{(\mathrm{M})}}{\text { Macronutrients }^{(\mathrm{l})}}$} & \multirow[t]{2}{*}{ Stock Solution $\left(\mathrm{g} \mathrm{L}^{-1}\right)$} & \multicolumn{4}{|c|}{$\begin{array}{l}\text { Treatments ionic strength }(I) \\
\left(\mathrm{mM} \mathrm{L}^{-1}\right)\end{array}$} \\
\hline & & $25 \%$ & $50 \%$ & $75 \%$ & $100 \%$ \\
\hline $\mathrm{NH}_{4} \mathrm{H}_{2} \mathrm{PO}_{4}$ & 115.0 & 0.12 & 0.24 & 0.47 & 0.63 \\
\hline $\mathrm{KNO}_{3}$ & 101.1 & 0.84 & 1.68 & 2.52 & 3.36 \\
\hline $\mathrm{Ca}\left(\mathrm{NO}_{3}\right)_{2} \cdot 4 \mathrm{H}_{2} \mathrm{O}$ & 236.1 & 0.97 & 1.95 & 3.90 & 5.19 \\
\hline $\mathrm{MgSO}_{4} \cdot 7 \mathrm{H}_{2} \mathrm{O}$ & 246.5 & 0.51 & 1.02 & 2.03 & 2.71 \\
\hline Micronutrients & & $25 \%$ & $50 \%$ & $75 \%$ & $100 \%$ \\
\hline (1) $\mathrm{H}_{3} \mathrm{BO}_{3}$ & 2.86 & 2.95 & 5.90 & 11.8 & 15.7 \\
\hline $\mathrm{MnCl}_{2} \cdot 4 \mathrm{H}_{2} \mathrm{O}$ & 1.81 & 1.86 & 3.71 & 7.42 & 9.90 \\
\hline $\mathrm{ZnSO}_{4} \cdot 7 \mathrm{H}_{2} \mathrm{O}$ & 0.22 & 0.22 & 0.45 & 0.91 & 1.20 \\
\hline $\mathrm{CuSO}_{4} \cdot 5 \mathrm{H}_{2} \mathrm{O}$ & 0.08 & 0.08 & 0.16 & 0.33 & 0.44 \\
\hline $\mathrm{H}_{2} \mathrm{MoO}_{4} \cdot \mathrm{H}_{2} \mathrm{O}$ & 0.02 & 0.02 & 0.04 & 0.08 & 0.11 \\
\hline Fe Solution $^{(2)}$ & & $25 \%$ & $50 \%$ & $75 \%$ & $100 \%$ \\
\hline Fe-EDTA & 26.1 & 0.07 & 0.05 & 0.11 & 0.14 \\
\hline $\mathrm{FeSO}_{4} \cdot 7 \mathrm{H}_{2} \mathrm{O}$ & 24.9 & 0.06 & 0.05 & 0.10 & 0.14 \\
\hline
\end{tabular}

$(\mathrm{M})=$ Molar; $(1)=$ dilution in distilled water and volume completed to $1 \mathrm{~L} ;(2)=$ dilution in $700 \mathrm{~mL}$ distilled water containing $268 \mathrm{~mL}$ $\mathrm{NaOH}(40 \mathrm{~g} / \mathrm{L})$ and volume completed to $1 \mathrm{~L}$.

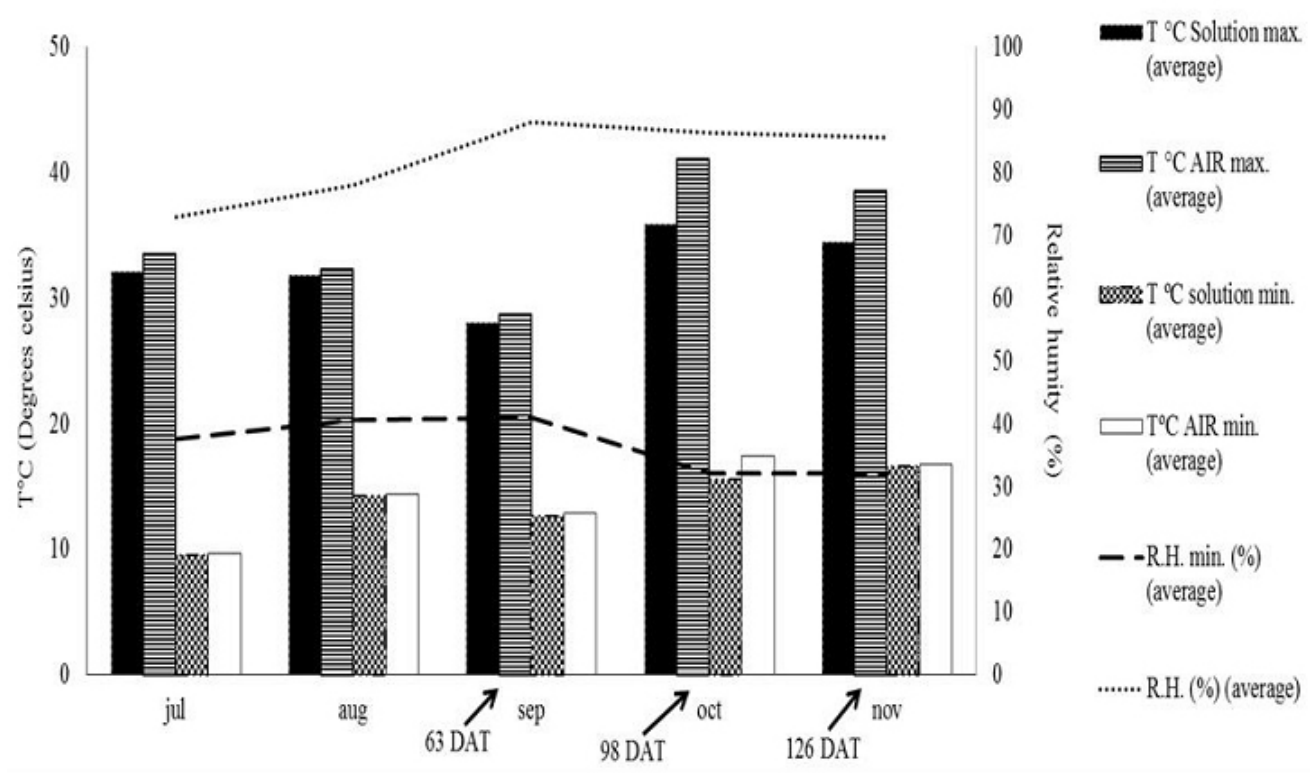

FIGURE 1 - Humidity and temperatures data of nutrient solutions in greenhouse recorded over the cultivation period for "Araticum-de-terra-fria" seedlings under different ionic strengths of complete nutrient solution $\mathrm{n}^{\circ} 2$ of Hoagland and Arnon (1950). Arrows indicate the dates when leaf gas exchange was evaluated. DAT (Days after transplanting). 
TABLE 2- Growth of "Araticum-de-terra-fria" seedlings under different ionic strengths $(I)$ of complete nutrient solution $n^{\circ} 2$ of Hoagland and Arnon (1950) over time. Results are the means and each value was obtained from 5 plants per Treatment $(n=5)$ Uppercase letters represent the comparison of a same ionic strength at different harvests and Lowercase letters represent the comparison of the different each harvest; distinct letters indicate significant differences according to Tukey's Test at $5 \%(P \leq 0.05)$. DAT, Days After Transplanting.

\begin{tabular}{|c|c|c|c|c|c|c|c|c|}
\hline \multicolumn{5}{|c|}{ Leaf number (units) } & \multicolumn{4}{|c|}{ Diameter $(\mathbf{m m})$} \\
\hline Treat/ & $25 \% I$ & $50 \% I$ & $75 \% I$ & $100 \% I$ & $25 \% I$ & $50 \% I$ & $75 \% I$ & $100 \% I$ \\
\hline 28 & $4.8 \mathrm{Ac}$ & $6.0 \mathrm{Ac}$ & $5.6 \mathrm{Ac}$ & $5.4 \mathrm{Ab}$ & $2.1 \mathrm{Ad}$ & $2.3 \mathrm{Ac}$ & $2.2 \mathrm{Ad}$ & $2.18 \mathrm{Ad}$ \\
\hline 56 & $9.2 \mathrm{Bbc}$ & 14.6 Abc & $10 \mathrm{Bbc}$ & $9.4 \mathrm{Bb}$ & $2.9 \mathrm{Ac}$ & $3.1 \mathrm{Abc}$ & $3.1 \mathrm{Acd}$ & $3.08 \mathrm{Ac}$ \\
\hline 84 & $12.8 \mathrm{Bb}$ & $15.6 \mathrm{ABb}$ & $16 \mathrm{Ab}$ & $15 \mathrm{Bb}$ & $3.3 \mathrm{Abc}$ & $3.9 \mathrm{Ab}$ & $3.7 \mathrm{Ac}$ & $3.60 \mathrm{Ac}$ \\
\hline 112 & $20.4 \mathrm{Ba}$ & $28.4 \mathrm{a}$ & $28 \mathrm{Aa}$ & $27.6 \mathrm{Aa}$ & $3.7 \mathrm{Bb}$ & $5.2 \mathrm{Aa}$ & $4.9 \mathrm{Ab}$ & $4.82 \mathrm{Ab}$ \\
\hline 140 & $24.4 \mathrm{Ba}$ & $28.6 \mathrm{Aa}$ & $29.2 \mathrm{Aa}$ & $28.4 \mathrm{Aa}$ & $5.466 \mathrm{Ba}$ & $6.058 \mathrm{Aa}$ & $5.984 \mathrm{Aa}$ & $5.952 \mathrm{Aa}$ \\
\hline \multicolumn{5}{|c|}{ Height (cm) } & \multicolumn{4}{|c|}{ Stem dry matter (g) } \\
\hline $\begin{array}{c}\text { Treat/ } \\
\text { DAT }\end{array}$ & $25 \% I$ & $50 \% I$ & $75 \% I$ & $100 \% I$ & $25 \% I$ & $50 \% I$ & $75 \% I$ & $100 \% I$ \\
\hline 28 & $7.08 \mathrm{Ab}$ & $8.3 \mathrm{Ad}$ & $8.20 \mathrm{Ad}$ & $7.50 \mathrm{Ac}$ & $0.17 \mathrm{Aa}$ & $0.19 \mathrm{Ab}$ & $0.19 \mathrm{Ab}$ & $0.19 \mathrm{Ab}$ \\
\hline 56 & $14 \mathrm{Aa}$ & 13.9 Ac & $13.42 \mathrm{Ac}$ & $13.18 \mathrm{Ab}$ & $9 \mathrm{Aa}$ & $0.21 \mathrm{Ab}$ & $0.19 \mathrm{Ab}$ & $0.19 \mathrm{Ab}$ \\
\hline 84 & 15.6 Aa & $19 \mathrm{Ab}$ & $18.66 \mathrm{Ab}$ & 17.98 Aab & $0.3 \mathrm{Aab}$ & $0.32 \mathrm{Ab}$ & $0.32 \mathrm{Ab}$ & $0.32 \mathrm{Ab}$ \\
\hline 112 & $18.46 \mathrm{Ba}$ & $24.7 \mathrm{Aa}$ & $22.50 \mathrm{ABa}$ & $20.32 \mathrm{ABa}$ & $0.4 \mathrm{Bb}$ & $0.71 \mathrm{Aa}$ & $0.65 \mathrm{Aa}$ & $0.36 \mathrm{Ab}$ \\
\hline 140 & $18.60 \mathrm{Ba}$ & $25.4 \mathrm{Aa}$ & $25.04 \mathrm{ABa}$ & $21.36 \mathrm{ABa}$ & $0.44 \mathrm{Bb}$ & $0.8 \mathrm{Aa}$ & $0.66 \mathrm{ABa}$ & $0.60 \mathrm{Aa}$ \\
\hline \multicolumn{5}{|c|}{ Leaf area $\left(\mathrm{cm}^{2}\right)$} & \multicolumn{4}{|c|}{ Root dry matter (g) } \\
\hline $\begin{array}{c}\text { Treat/ } \\
\text { DAT }\end{array}$ & $25 \% I$ & $50 \% I$ & $75 \% I$ & $100 \% I$ & $25 \% I$ & $50 \% I$ & $75 \% I$ & $100 \% I$ \\
\hline 28 & $16 \mathrm{Ac}$ & $16.3 \mathrm{Ac}$ & $16 \mathrm{Ac}$ & $16.1 \mathrm{Ac}$ & $0.24 \mathrm{Aa}$ & $0.25 \mathrm{Ab}$ & $0.25 \mathrm{Ab}$ & $0.25 \mathrm{Ab}$ \\
\hline 56 & $33.9 \mathrm{Abc}$ & $37.5 \mathrm{Ac}$ & 35.9 Ac & $35.7 \mathrm{Abc}$ & $0.26 \mathrm{Aa}$ & $0.3 \mathrm{Ab}$ & $0.30 \mathrm{Ab}$ & $0.272 \mathrm{Ab}$ \\
\hline 84 & 58.8 Aab & $61.4 \mathrm{Abc}$ & $71.9 \mathrm{Ab}$ & 70.7 Aab & $1 \mathrm{Aa}$ & $0.33 \mathrm{Ab}$ & $0.33 \mathrm{Ab}$ & $0.32 \mathrm{Ab}$ \\
\hline 112 & $81.6 \mathrm{Ba}$ & $121 \mathrm{Aab}$ & $107 \mathrm{Aa}$ & 105.9 Aba & $0.42 \mathrm{Aa}$ & $0.83 \mathrm{Aa}$ & $0.75 \mathrm{Aa}$ & $0.66 \mathrm{Aa}$ \\
\hline 140 & $90.2 \mathrm{Ba}$ & $158.2 \mathrm{Aa}$ & $112.8 \mathrm{ABa}$ & $110.4 \mathrm{ABa}$ & $0.43 \mathrm{Ba}$ & $0.85 \mathrm{Aa}$ & $0.79 \mathrm{ABa}$ & $0.63 \mathrm{ABa}$ \\
\hline \multicolumn{5}{|c|}{ Leaf dry matter (g) } & \multicolumn{4}{|c|}{ Total dry matter (g) } \\
\hline $\begin{array}{c}\text { Treat/ } \\
\text { DAT }\end{array}$ & $25 \% I$ & $50 \% I$ & $75 \% I$ & $100 \% I$ & $\% I$ & $50 \% I$ & $75 \% I$ & $100 \% I$ \\
\hline 28 & $0.21 \mathrm{Aa}$ & $0.22 \mathrm{Ac}$ & $0.22 \mathrm{Ab}$ & $0.21 \mathrm{Ab}$ & $0.61 \mathrm{Ab}$ & $0.67 \mathrm{Ab}$ & $0.65 \mathrm{Ac}$ & $0.64 \mathrm{Ac}$ \\
\hline 56 & $0.28 \mathrm{Aa}$ & $0.29 \mathrm{Abc}$ & $0.28 \mathrm{Ab}$ & $0.29 \mathrm{Ab}$ & $0.74 \mathrm{Ab}$ & $0.79 \mathrm{Ab}$ & $0.77 \mathrm{bc}$ & $0.75 \mathrm{Ac}$ \\
\hline 84 & $0.32 \mathrm{Aa}$ & $0.35 \mathrm{Abc}$ & $0.35 \mathrm{Ab}$ & $0.33 \mathrm{Ab}$ & $0.93 \mathrm{Aab}$ & $1.02 \mathrm{Ab}$ & $1.03 \mathrm{Ac}$ & $0.98 \mathrm{Ac}$ \\
\hline 112 & $0.44 \mathrm{Ba}$ & $1.01 \mathrm{Aab}$ & $0.7 \mathrm{Aa}$ & $0.69 \mathrm{Aa}$ & $1.27 \mathrm{Ca}$ & $2.41 \mathrm{Aa}$ & $2.11 \mathrm{Aa}$ & $1.71 \mathrm{Bb}$ \\
\hline 140 & $0.448 \mathrm{Ba}$ & $1.014 \mathrm{Aa}$ & $0.873 \mathrm{Aa}$ & $0.831 \mathrm{Aa}$ & $1.32 \mathrm{Ba}$ & $2.6 \mathrm{Aa}$ & $2.23 \mathrm{ABa}$ & $2.12 \mathrm{ABa}$ \\
\hline
\end{tabular}




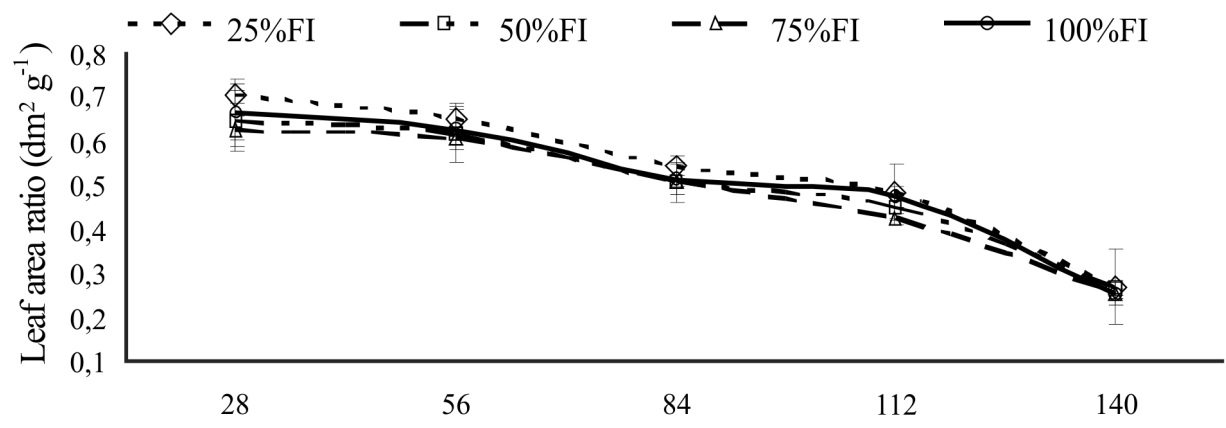

Days after transplant

A
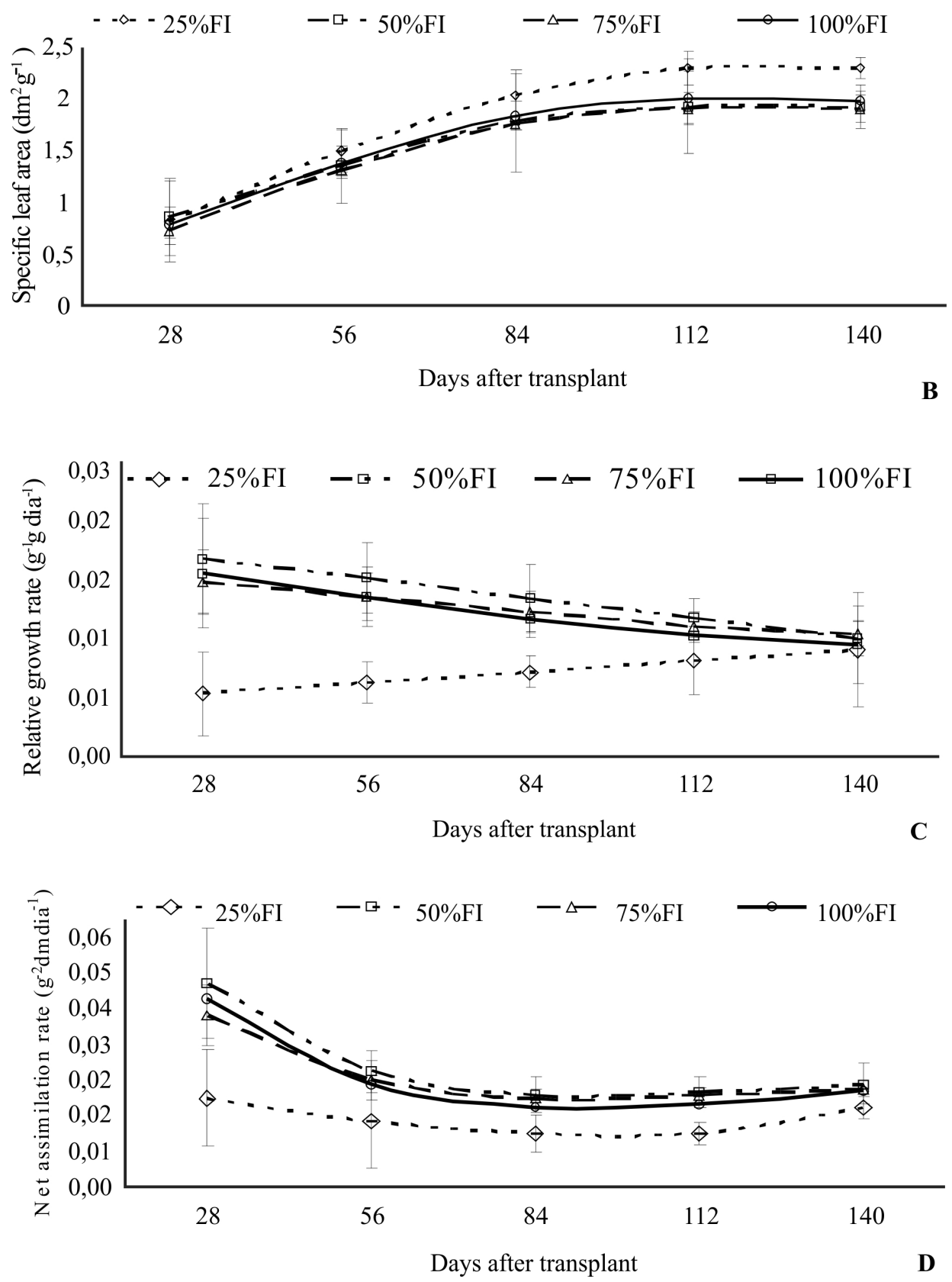


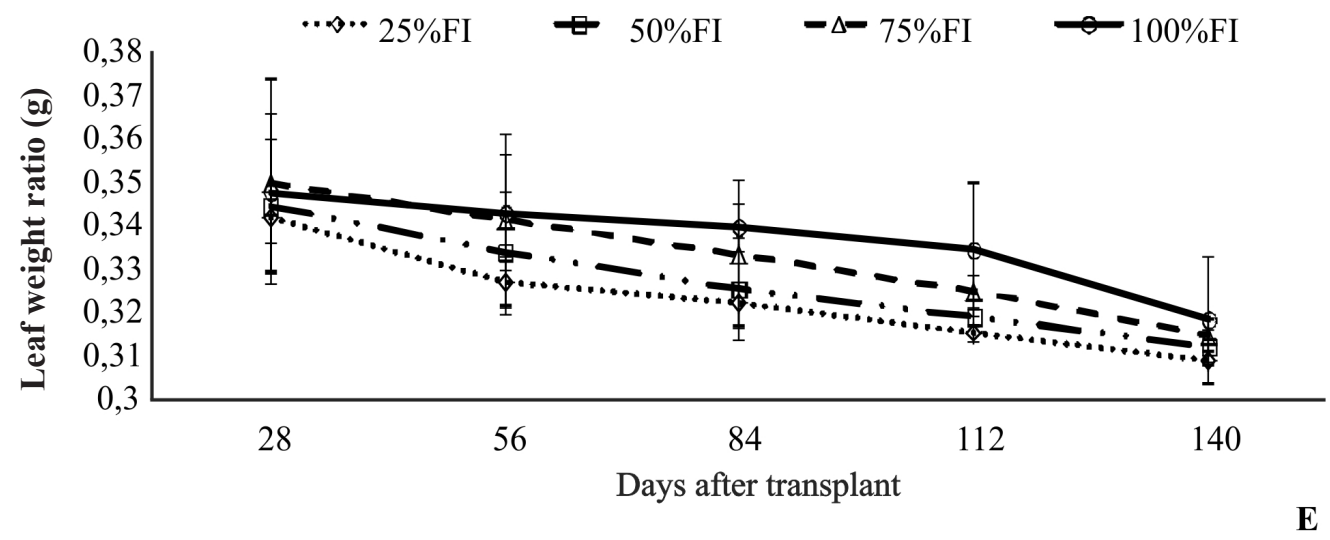

FIGURE 2- Physiological indexes for "Araticum-de-terra-fria" seedlings grown under different ionic strengths (I) of complete nutrient solution $\mathrm{n}^{\circ} 2$ of Hoagland and Arnon (1950). Results are the means $( \pm$ S.E. $)$ and each value was obtained from 5 plants per Treatment $(n=5)$ in 5 evaluation periods (28, 56, 84, 112 and 140 Days After Transplanting). A - Leaf Area Ratio (LAR); B - Specific Leaf Area (SLA); C - Relative Growth Rate (RGR); D - Net Assimilation Rate (NAR); E - Leaf Weight Ratio (LWR). Values adjusted by the exponential quadratic equation.
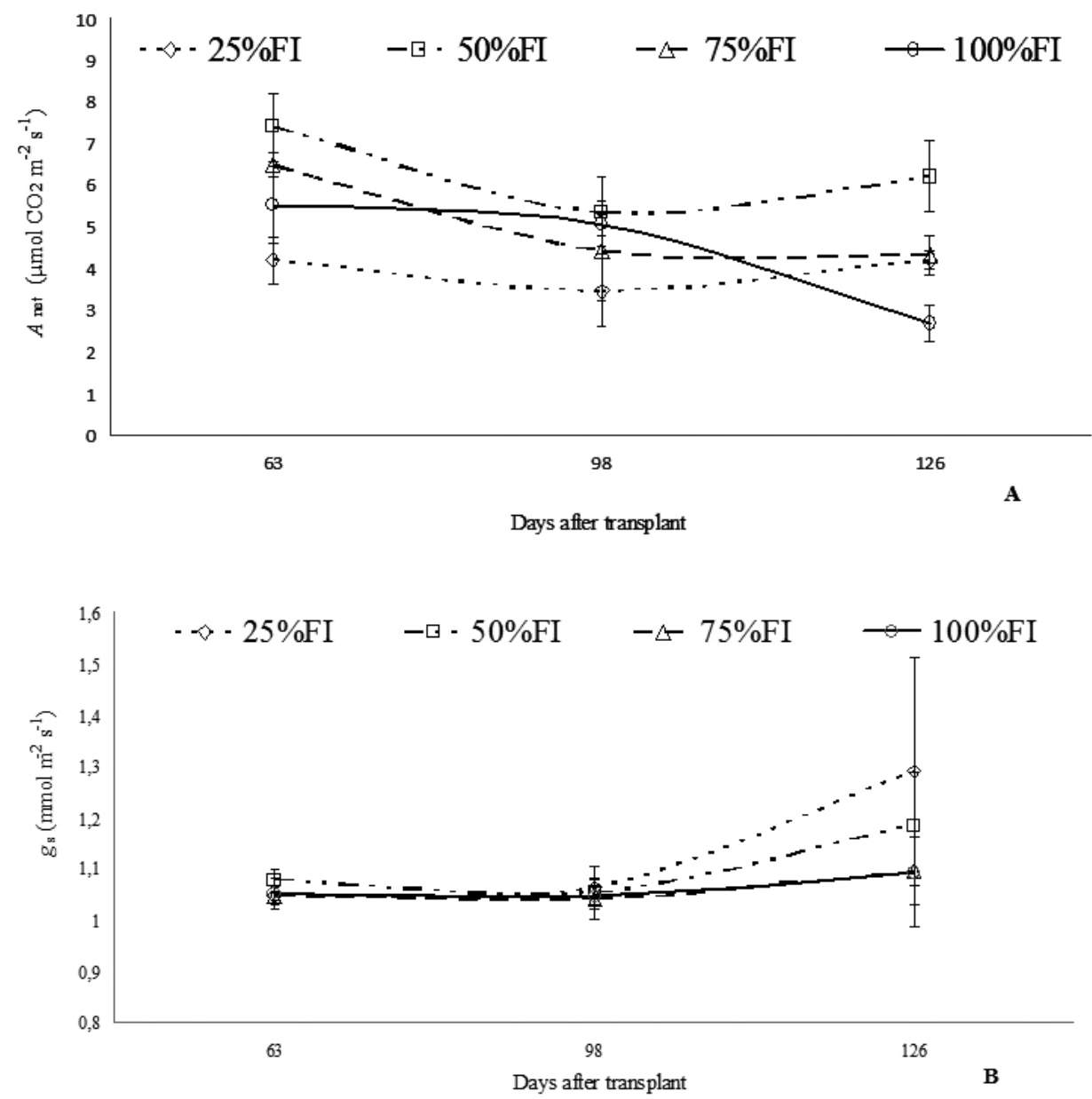

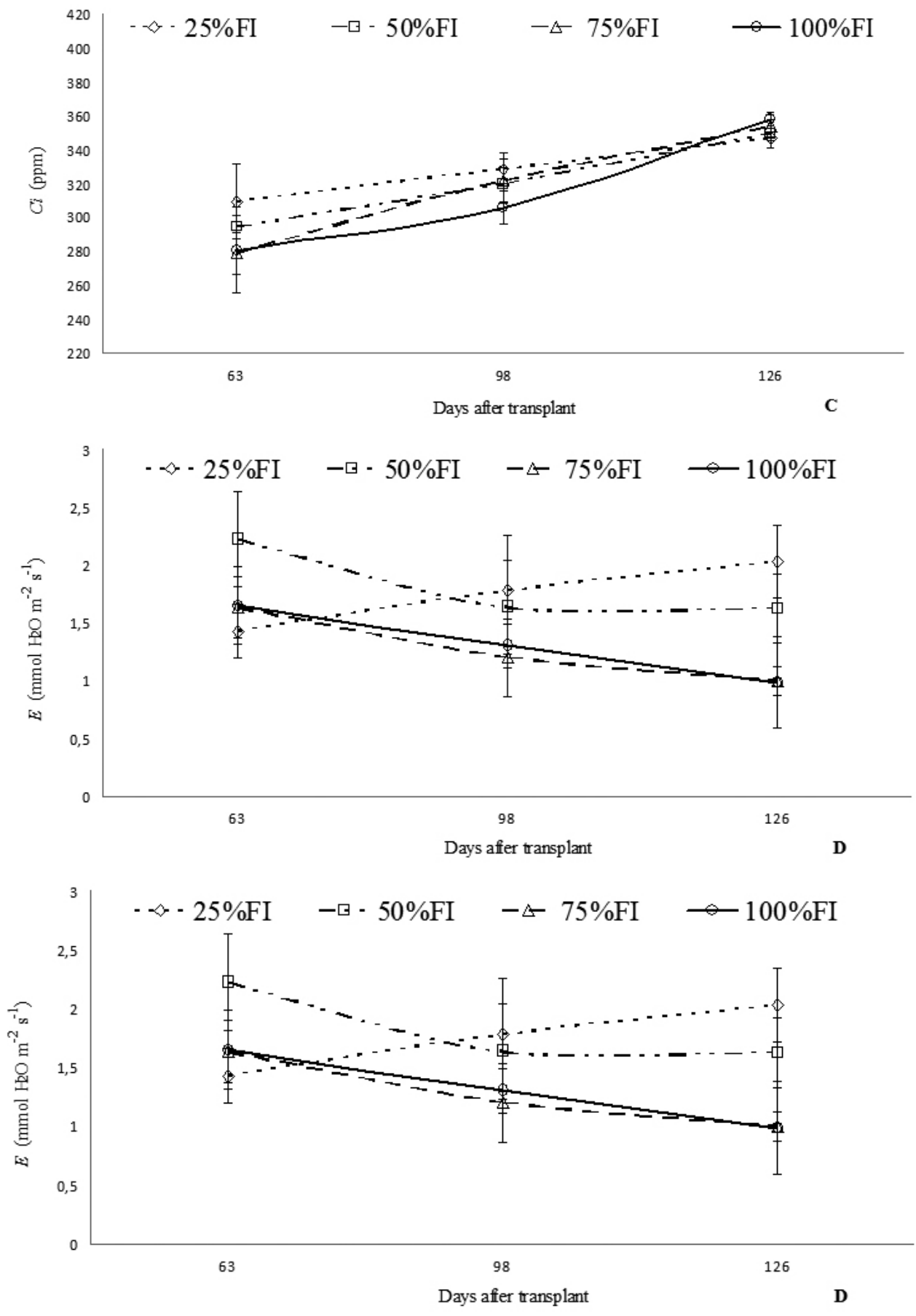

FIGURE 3-Leaf gas exchange for "Araticum-de-terra-fria" seedlings grown under four ionic strengths $(I)$ of complete nutrient solution $\mathrm{n}^{\circ} 2$ of Hoagland and Arnon (1950) in 3 periods (63, 98 and 126 Days After Transplanting). Results are the means ( \pm S.E.) and each value was obtained from 4 plants per Treatment $(n=4)$ in 4 different evaluation periods. $\mathrm{A}-\mathrm{Net} \mathrm{CO}_{2}$ assimilation rate $\left(A_{\text {net }}\right) ; \mathrm{B}$ - Stomatal conductance $\left(g_{\mathrm{s}}\right)$; C - Internal carbon concentration $\left(C_{\mathrm{i}}\right)$; D - Transpiration rate $(E)$; E - Water use efficiency (WUE); $\mathrm{F}$ - Instantaneous carboxylation efficiency $\left(A_{\text {net }} / C_{\mathrm{i}}\right)$. 

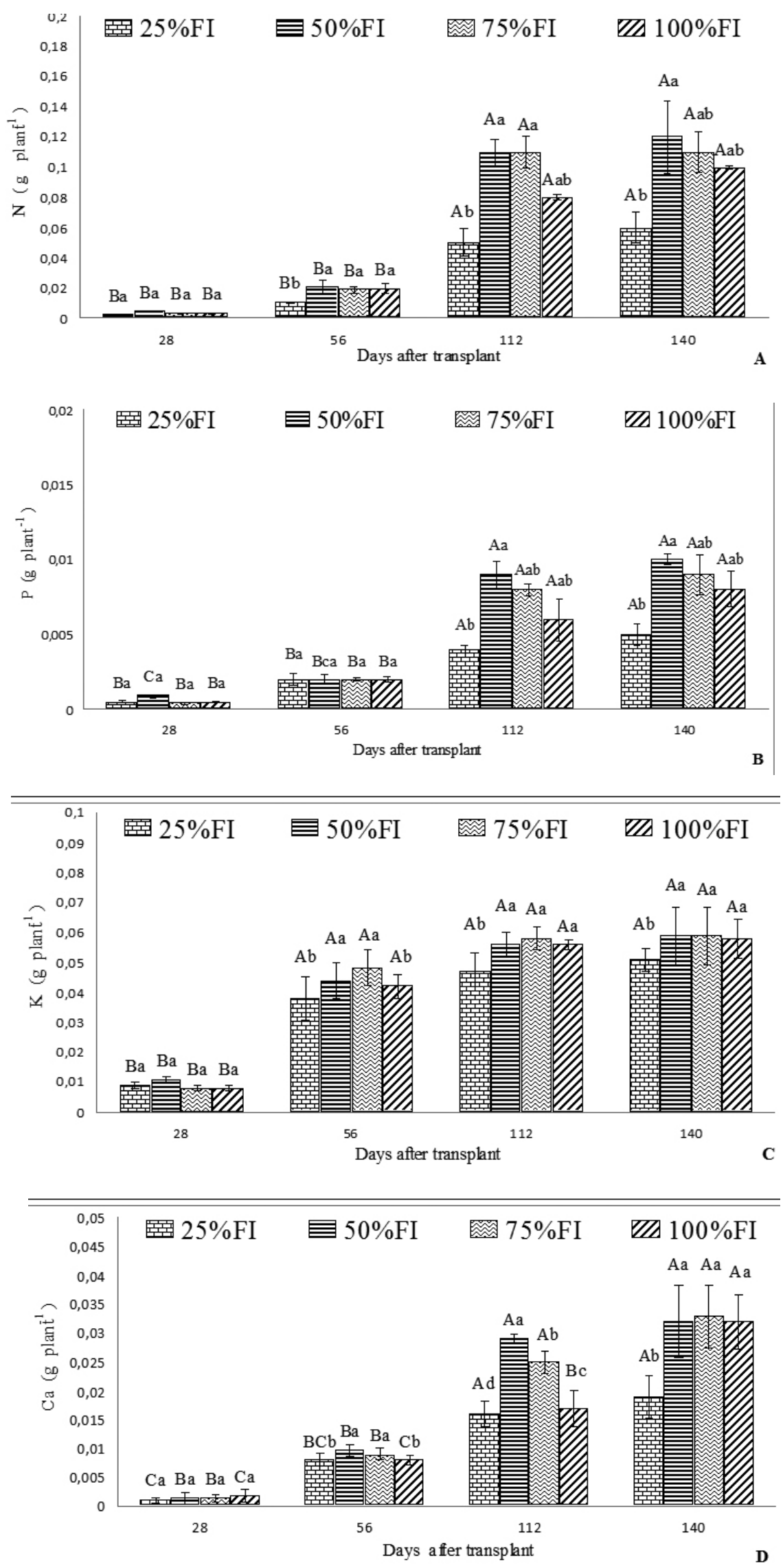


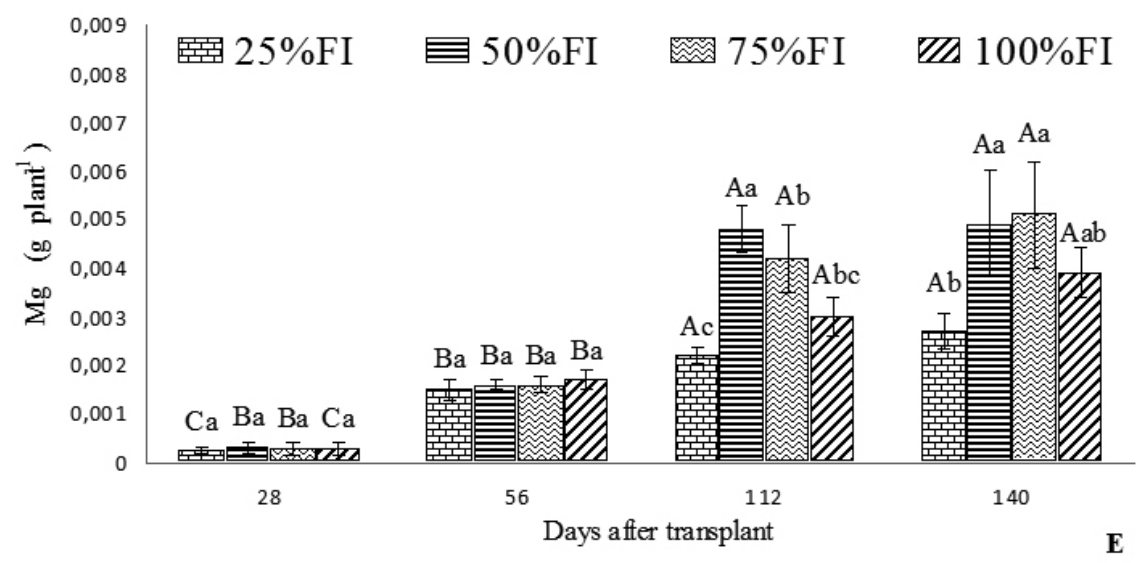

FIGURE 4-Leaf ion concentration as g plant ${ }^{-1} \mathrm{DM}$ (dry matter) determined for "Araticum-de-terra-fria" seedlings grown under different ionic strengths $(I)$ of complete nutrient solution $n^{\circ} 2$ of Hoagland and Arnon (1950) in 4 evaluation periods (28, 56, 112 and 140 Days After Transplanting). Results are the means ( \pm S.E.) and each value was obtained from four plants per Treatment $(n=4)$. Uppercase letters represent the comparison of a same ionic strength at different harvests; distinct letters indicate significant differences according to Tukey's Test at 5\% $(P \leq 0.05)$. A - Nitrogen (N); B - Phosphorus (P); C - Potassium (K); D - Calcium (Ca); E - Sulfur (S); F - Magnesium (Mg). Lowercase letters represent the comparison of different ionic strengths at each harvest; distinct letters indicate significant differences according to Tukey's Test at $5 \%(P \leq 0.05)$.

TABLE 3 - Mean values of the physiological indexes LAR (Leaf Area Ration), SLA (Specific Leaf Area), RGR (Relative Growth Rate), NAR (Net Assimilation Rate) and LWR (Leaf Weight Rate) for "Araticum-de-terra-fria" seedlings grown under different ionic strengths $(I)$ of nutritive solution $\mathrm{n}^{\circ} 2$ of Hoagland and Arnon (1950) over the cultivation period. Results are the means and each value was obtained from 5 plants per Treatment $(n=5)$. For each Physiological Index, means followed by distinct letters significantly differed according to Tukey's Test at $5 \%(\mathrm{P} \leq 0.05)$.

\begin{tabular}{cccccc}
\hline Treatment / P.I. & LAR & SLA & RGR & NAR & LWR \\
\hline $25 \% I$ & $0.5272 \mathrm{a}$ & $1.788 \mathrm{a}$ & $0.0072 \mathrm{~b}$ & $0.0153 \mathrm{~b}$ & $0.3228 \mathrm{a}$ \\
$50 \% I$ & $0.4949 \mathrm{a}$ & $1.568 \mathrm{a}$ & $0.0134 \mathrm{a}$ & $0.0273 \mathrm{a}$ & $0.3306 \mathrm{a}$ \\
$75 \% I$ & $0.4822 \mathrm{a}$ & $1.519 \mathrm{a}$ & $0.0124 \mathrm{ab}$ & $0.0245 \mathrm{ab}$ & $0.3371 \mathrm{a}$ \\
$100 \% I$ & $0.5040 \mathrm{a}$ & $1.598 \mathrm{a}$ & $0.0121 \mathrm{ab}$ & $0.0246 \mathrm{ab}$ & $0.3410 \mathrm{a}$ \\
\hline$F$ & 0.72 & 0.32 & 6.53 & 4.48 & 0.22 \\
$P>F$ & 0.5569 & 0.8128 & 0.0043 & 0.0182 & 0.879 \\
$C V(\%)$ & 11.47 & 19.44 & 21.58 & 25 & 10.78 \\
\hline
\end{tabular}

\section{ACKNOWLEDGMENTS}

We thank the Coordination for the Improvement of Higher Education Personnel (CAPES) for financial support.

\section{REFERENCES}

AFROUSHEH,M.;ARDALAN, M.; HOKMABADI, H.; AFROUSHEH, M. Nutrient deficiency disorders in Pistacia vera seedling rootstock in relation to cophysiological, biochemical characteristics and uptake pattern of nutrients. Scientia Horticulture, Amsterdam, v.124, n.2, p.141-148, 2010.
ALVAREZ, S.; NAVARRO, A.; NICOLAS, E.; SANCHEZ-BLANCO, M.J. Transpiration, photosynthetic responses, tissue water relations and dry mass partitioning in Callistemon plants during drought conditions. Scientia Horticulturae, Amsterdam, v.129, n.2, p.306-312, 2011.

ALVES, E.U.A.; ANDRADE, L.A.; BARROS, H.H.A.; GONÇALVES, E.P.; GERLANDIO, A.U.A. Substrate for tests of seedlings emergency and seed vigor of Erythrina velutina Willd., Fabaceae. Semina, Londrina, v.29, n.2, p.69-82, 2008. 
BAR-YOSEF, B. Crops response to solution recycling in closed loop irrigation systems. In: RAVIV, M.; LIETH, J.H. (Ed.). Soilless culture: theory and practice. Amsterdam: Elsevier, 2008. p.341-424.

BAR-YOSEF, B.; MATTSON, N.S.; LIETH, H.J. Effects of NH4:NO3: urea ratio on cut roses yield, leaf nutrients content and proton efflux by roots in closed hydroponic system. Scientia Horticulturae, Amsterdam, v.122, n.4, p.610-619, 2009.

BATISTA, M.M.F.; VIÉGAS, I.J.M.; FRAZÃO, D.A.C.; THOMAZ, M.A.A.; SILVA, R.C.L. Efeito da omissão de macronutrientes no crescimento, nos sintomas de deficiências nutricionais e na composição mineral em gravioleiras (Annona muricata). Revista Brasileira de Fruticultura, Jaboticabal, v.25, n.2, p.315-128, 2003.

BENLLOCH-GONZÁLEZ, M.; ROMERA, C.; CRITESCU, S.; HARREN, F.; FOURNIER, J.M.; BENLLOCH, M. $\mathrm{K}^{+}$starvation inhibits water-stressinduced stomatal closure via ethylene synthesis in sunflower plants. Journal of Experimental Botany, Oxford, v.61 p.1139-1145, 2010.

BETTIOL NETO, J. E.; PIO, R.; BUENO, S.C.S.; BASTOS, D.C.; SCARPARE FILHO, J. Enraizamento de estacas dos porta-enxertos Araticum-de-Terra-Fria (Rollinia sp.) e AraticumMirim (Rollinia emarginata Schltdl.) para anonáceas. Ciência e Agrotecnologia, Lavras, v.30, p.10771082, 2006.

CAMPOSTRINI, E.; YAMANISHI, O.K.; MARTINEZ, C.A. Leaf gas exchange characteristics of four papaya genotypes during different stages of development. Revista Brasileira de Fruticultura, Jaboticabal, v.23, p.522-525, 2010.

CHAPIN, F.S. The mineral nutrition of wild plants. Annual Review Ecology and Systematics, Palo Alto, v.11, p.233-60, 1980.

CHATZISSAVVIDIS, C.; THERIOS, I. Response of four olive (Olea europaea L.) cultivars to six B concentrations: Growth performance, nutrient status and gas exchange parameters. Scientia Horticulturae, Amsterdam, v.127, n.1, p.29-38, 2010.
DAVID, E.F.S.; BOARO, C.S.F. Translocação orgânica, produtividade e rendimento de óleo essencial de Mentha piperita L. cultivada em solução nutritiva com variação dos níveis de $\mathrm{N}, \mathrm{P}$, $\mathrm{K}$ e Mg. Revista Brasileira de Plantas Medicinais, Botucatu, v.11, n.3 p.236-246, 2009.

DAVID, E.F.S.; MISCHAN, M.M.; BOARO, C.S.F. Desenvolvimento e rendimento de óleo essencial de menta (Mentha x piperita L.) cultivada em solução nutritiva com diferentes níveis de fósforo. Biotemas, Florianópolis, v.20, n.2, p.15-26, 2007.

DE BARROS, I.; GAISER, T.; LANGE, F.M.; ROMHELD, V. Mineral nutrition and water use patterns of a maize/cowpea intercrop on a highly acidic soil of the tropic semiarid. Field Crops Research, Amsterdam, v.101, p.26-36, 2007.

DINAKAR, C.; DJILIANOV, D.; BARTELS, D. Photosynthesis in desiccation tolerant plants: Energy metabolism and antioxidative stress defense. Plant Science, Limerick, v. 182, p.29-41, 2012.

DING, Y.; CHANG, C.; LUO, W.; WU, Y.; REN, X.; WANG, P.; XU, G. High potassium aggravates the oxidative stress inducedy by magnesium deflciency in rice leaves. Pedosphere, Nanjing, v.18, n.3, p.316$327,2008$.

EPSTEIN, E.; BLOOM, A. Nutrição mineral de plantas: princípios e perspectivas. 2.ed. Londrina: Planta, 2006. 416 p.

EVETT, S. R.; SCHWARTZ, R.C.; CASANOVA, J.J.; HENG, L.K. Soil water sensing for water balance, ET and WUE. Agricultural Water Management, Amsterdam, v. 104, p.1-9, 2012.

FAN, M.; BIE, Z.; KRUMBEIN, A.; SCHWARZ, D. Salinity stress in tomatoes can be alleviated by grafting and potassium depending on the rootstock and K-concentration employed. Scientia Horticulturae, Amsterdam, v.130, n.3, p.615-623, 2011.

FRANCO, C.F., PRADO, R.M. Nutrição de micronutrientes em mudas de goiabeira em resposta ao uso de soluções nutritivas. Acta Scientiarum Agronomy, Maringá, v. 30, n.3, p.403-408, 2008.

GILL, S. S.; KHAN, N. A.; TUTEJA, N. Cadmium at high dose perturbs growth, photosynthesis and nitrogen metabolism while at low dose it up regulates sulfur assimilation and antioxidant machinery in garden cress (Lepidium sativum L.). Plant Science, Limerick, v.182, n.0, p.112-120, 2012. 
HELBEL JUNIOR, C.; REZENDE, R.; FREITAS, P.S.L.; GONÇALVES, A.C.A.; FRIZZONE, J.A. Influência da condutividade elétrica, concentração iônica e vazão de soluções nutritivas na produção de alface hidropônica. Ciencia e Agrotecnológia, Lavras, v.32, n.4, p.1242-1247, 2008.

HOAGLAND, D.R.; ARNON, D.I. The water culture method for growing plants without soils. Berkeley: Califórnia Agricultura Expermental Station, 1950. 32 p.

IQBAL, N.; KHAN, N.A.; NAZAR, R.; SILVA, J.A.T. Ethylene-stimulated photosynthesis results from increased nitrogen and sulfur assimilation in mustard types that differ in photosynthetic capacity. Environmental and Experimental Botany, Amsterdam, v.78, n.0, p.84-90, 2012.

KUMAR, S.; DEY, P. Effects of different mulches and irrigation methods on root growth, nutrient uptake, water-use efficiency and yield of strawberry. Scientia Horticulturae, Amsterdam, v.127, n.3, p.318-324, 2011.

LAMBERS, H.; CHAPIN, F.S.; PONS, T.L. Plant physiological ecology. $2^{\text {nd }}$ ed. New York: SpringerVerlag, 2008. 640 p.

LARCHER, W. Ecofisiologia vegetal. São Carlos: RIMA Artes e Textos, 2006. 532p.

LITTELL, R.C.; STROUP, W.C.; FREUND, R.J. SAS for linear models. $4^{\text {th }}$ ed. Cary: SAS Institute, 2002 .

MAATHUIS, F.J. Physiological functions of mineral macronutrients. Current Opinion of Plant Biology, Amsterdam, v.12, n.3, p.250-258, 2009.

MAHOUACHI, J.; SOCORRO, A.R.; TALON, M. Responses of papaya seedlings (Carica papaya L.) to water stress and rehydration: growth, photosynthesis and mineral nutrient imbalance. Plant and Soil, Berlin, v.281, n.1/2, p.137-146, 2006.

MCAINSH, M.R.; PITTMAN, J.K. Tansley review: Shaping the calcium signature. New Phytologist, Malden, v.181, n.2, p.275-294, 2009.

MITTAL, M; JUVEAL, V; SINGH, A. Antidiabetic and crioprotective effect of Annona squamosa L. leaves on diabetic wistear albino rat. Pharmacology, Basel, v.2, p.908-13, 2010.
NAEEM, M.; KHAN, M.M.A.; MOINUDDIN; IDREES, M.; AFTAB, T. Phosphorus ameliorates crop productivity, photosynthetic efficiency, nitrogen-fixation, activities of the enzymes and content of nutraceuticals of Lablab purpureus L. Scientia Horticulturae, Amsterdam, v.126, n.2, p.205-214, 2010.

OKOYE, T.C.; AKAH, P.A.; EZIKE, A.C.; OKOYE, M.O.; ONYETO, C.A.; NDUKWU, F.; OHAEGBULAM, E.; KELE, L. Evaluation of the acute and sub-acute toxicity of Annona senegalensis root bark extracts. Asian Pacific Journal of Tropical Medicine, Singapore, v.5, n.4, p.277-282, 2012.

PADILLA, I.M.G.; ENCINA, C.L. The use of consecutive micrografting improves micropropagation of cherimoya (Annona cherimola Mill.) cultivars. Scientia Horticulturae, Amsterdam, v.129, n.1, p.167-169, 2011.

RADFORD, P.S. Growth analysis formulae: their use and abuse. Crop Science, Madison, v.7, p.171$175,1967$.

RESH, H.M. Hydroponic Food Production: A definitive guidebook of soiless food-growing methods. $6^{\text {th }}$ ed. New Jersey: Newconcept Press, 2001. 290 p.

SEVIL KILINC, S.; ERTAN, E.; SEFEROGLU, S. Effects of different nutrient solution formulations on morphological and biochemical characteristics of nursery fig trees grown in substrate culture. Scientia Horticulturae, Amsterdam, v.13, n.1, p.20-27, 2007.

SUN, H.Y.; LIU, C.M.; ZHANG, X.Y.; SHEN, Y.J.; ZHANG, Y.Q. . Effects of irrigation on water balance, yield and WUE of winter wheat in the North China Plain. Agricultural Water Management, Amsterdam, v. 85, n.1-2, p.211-218, 2006.

TAIZ, L.; ZEIGER, E. Plant physiology. $5^{\text {th }}$ ed. Sunderland: Sinauer Associates, 2010. 690 p.

TAN, W; QW, M.; BRESTIC, M.; OLSOVSKA, $\mathrm{K}$; YANG, X. Photosynthesis is improved by exogenous calcium in heat-stressed tobacco plants. Journal of Plant Physiology, Sttugart, v.168, n.17, p.2063-2071, 2011.

THONGBAI, P.; KOZAI, T.; OHYAMA, K. $\mathrm{CO}_{2}$ and air circulation effects on photosynthesis and transpiration of tomato seedlings. Scientia Horticulturae, Amsterdam, v.126, n.3, p.338-344, 2010 . 
TUCCI, M.L.S.A.; MODOLO, V.A.; ERISMANN, N.M.; MACHADO, E.C. Gas exchanges in peach palms as a function of the spad chlorophyll meter readings. Revista Brasileira de Fruticultura, Jaboticabal, v.33,n.2, p.267-274, 2011.

URBAN, O.; HRSTKA, M.; ZITOVÁ, M.; HOLIŠOVÁ, P.; SPRTOVÁ, M.; KLEM, K.; CALFAPIETRA, C.; DE ANGELIS, P.; MAREK, M.V. Effect of season, needle age and elevated $\mathrm{CO} 2$ concentration on photosynthesis and Rubisco acclimation in Picea abies. Plant Physiology and Biochemistry, Paris, v.58, n.0, p.135-141, 2012.
WANG, X.; WANG, K.Y.; ZHAO, X.Z.Q.; CAI, X.W.D.; HOOGMOED, W.B.; OENEMA, O. Nutrient management adaptation for dryland maize yields and water use efficiency to long-term rainfall variability in China. Agricultural Water Management, Amsterdam, v.97, n.9, p.1344-1350, 2010.

WARD, C.L.; KLEINERT, A.; SCORTECCI, K.C.; BENEDITO, V.A.; VALENTINE, A.J. Phosphorusdeficiency reduces aluminium toxicity by altering uptake and metabolism of root zone carbon dioxide. Journal of Plant Physiology, Sttugart, v.168, n.5, p.459-465, 2011. 